Situs Jurnal : $\underline{\text { http://ejurnal.stiepancasetia.ac.id/index.php/jieb }}$

Jilid 4 Nomor 1 Maret 2018

Hal $110-126$

\title{
ANALISIS LAPORAN KEUANGAN UNTUK MENILAI KINERJA KEUANGAN PADA PT. KAPUAS TATA STEEL BANJARBARU
}

\section{Hana Febrina Sari dan Adi Rahman*}

Abstract: The purpose of this study is to determine the calculation of financial performance at PT. Kapuas Tata Steel Banjarbaru based on the liquidity ratio, solvency ratio, activity ratio and profitability ratio. This research is conducted by using qualitative research methods with comparative descriptive approach used by the company with the method in accordance with the theoretical studies that have been presented. Sources of data in this study there are two types of primary data and secondary data. The results of this study indicate that the liquidity ratio fluctuates (up / down), which in 2015 is said to be good because it meets industry standards. Level of solvency ratio of PT. Kapuas Tata Steel Banjarbaru is still considered not good because in the year 2013-2017 is above the industry average. Activity ratio rate of PT. Kapuas Tata Steel Banjarbaru fluctuate, where the year 2016-2017 is said to be good because it occurs exceeds the industry standard.

Keywords: financial performance, liquidity ratio, solvency ratio, activity ratio, profitability ratio

Abstrak: Tujuan dari penelitian ini adalah untuk mengetahui perhitungan kinerja keuangan pada PT. Kapuas Tata Steel Banjarbaru berdasarkan rasio likuiditas, solvabilitas, aktivitas dan profitabilitas. Penelitian ini dilakukan dengan menggunakan metode penelitian kualitatif dengan pendekatan deskriptif komparatif digunakan perusahaan dengan metode yang sesuai dengan kajian teori yang telah dipaparkan. Sumber data dalam penelitian ini ada dua jenis yaitu data primer dan data sekunder. Hasil penelitian ini menunjukkan bahwa rasio likuiditas mengalami fluktuatif (naik/turun), dimana pada tahun 2015 dikatakan baik karena memenuhi standar industri. Tingkat rasio solvabilitas PT. Kapuas Tata Steel Banjarbaru masih dianggap kurang baik karena pada tahun 2013-2017 berada di atas rata-rata industri. Tingkat rasio aktivitas PT. Kapuas Tata Steel Banjarbaru mengalami fluktuatif, dimana tahun 2016-2017 dikatakan baik karena terjadi melebihi standar industri.

Kata kunci : kinerja keuangan, rasio likuiditas, rasio solvabilitas, rasio aktivitas, rasio profitabilitas

\section{Latar Belakang}

Perkembangan ekonomi dewasa ini menunjukkan arah yang semakin menyatu dengan ekonomi Regional dan Internasional yang dapat menunjang sekaligus dapat berdampak kurang menguntungkan, sementara itu perkembangan dapat bergerak dengan cepat dengan tantangan yang semakin komplek. Persaingan antara perusahaan semakin tinggi dengan memasuki era globalisasi yang dengan demikian perusahaan dapat membaca arah perkembangan ekonomi serta melakukan persiapan-persiapan dalam menghadapi persaingan tersebut dengan merestrukturisasikan sektor-sektor internnya dalam mewujudkan perusahaan yang siap berkompetisi baik dalam persaingan bisnis maupun peningkatan pemenuhan pelayanan 
terhadap masyarakat baik itu perusahaan swasta maupun perusahaan milik negara. Salah satu sektor intern perusahaan yang paling vital adalah sektor keuangan yang merupakan kekuatan utama yang dapat mempengaruhi secara langsung terhadap sektor intern lainnya dalam perusahaan. Oleh karena itu, dibutuhkan profesionalisme dalam pengelolaan laporan keuangan perusahaan.

PT. Kapuas Tata Steel Banjarbaru adalah perusahaan yang menghasilkan komoditas berupa paku dan beton neser. Sebagai perusahaan yang terus berkembang, PT. Kapuas Tata Steel Banjarbaru juga harus memperhatikan kinerja perusahaannya, agar selalu bisa memberikan laporan keuangnan yang akurat untuk diberikan kepada investor atau pihak-pihak lain yang terkait. Kualitas dari laporan keuangan yang dihasilkan sangat mempengaruhi perilaku dari stakeholders terhadap perusahaan, seperti pajak yang ditetapkan oleh pemerintah dan tambahan modal yang bersedia diberikan oleh investor. Laporan keuangan yang berkualitas juga menunjukkan kepada publik bahwa PT. Kapuas Tata Steel Banjarbaru dikelola secara professional, sehingga kepercayaan publik terhadap produk-produk yang dihasilkan juga ikut meningkat.

Berdasarkan pada latar belakang yang telah dikemukakan, maka penelitian ini ingin mengetahui kinerja keuangan dari PT. Kapuas Tata Steel Banjarbaru dilihat dari rasio likuiditas, rasio solvabilitas, rasio aktivitas, dan rasio profitabilitas.

\section{Kajian Literatur}

Likuiditas menunjukkan kemampuan suatu perusahaan untuk memenuhi kewajiban keuangannya yang harus segera dipenuhi atau kemampuan perusahaan untuk memenuhi kewajiban jangka pendeknya. Perusahaan yang mampu memenuhi kewajiban keuangannya tepat waktu berarti perusahaan tersebut dalam keadaan likuid, sebaliknya kalau perusahaan tidak dapat segera memenuhi kewajiban keuangannya pada saat ditagih berarti perusahaan tersebut dalam keadaan inlikuid.

Solvabilitas menunjukkan kemampuan perusahaan untuk memenuhi kewajiban keuangannya, apabila perusahaan tersebut dilikuidasi, solvabilitas ini dapat dihitung dari pospos yang sifatnya jangka panjang seperti aktiva tetap dan hutang jangka panjang. Suatu perusahaan dikatakan solvabel apabila perusahaan tersebut mempunyai aktiva atau kekayaan yang cukup untuk membayar semua hutang-hutangnya, sebaliknya apabila jumlah aktiva tidak cukup atau lebih kecil dari pada jumlah hutangnya, berarti perusahaan tersebut dalam keadaaan insolvabel. Baik perusahaan yang insolvabel maupun yang ilikuid menunjukkan keadaan keuangan yang kurang baik, karena kedua-duanya pada suatu waktu akan menghadapi kesulitan keuangan.

Aktivitas (activity ratio) digunakan untuk mengukur efektivitas perusahaan dalam menggunakan aktiva yang dimilikinya mengukur jangka waktu penagihan piutang selama satu periode atau berapa kali dana yang diinvestasikan dalam piutang ini berputar dalam satu periode Profitabilitas tujuannya untuk melihat perkembangan perusahaan dalam rentang waktu tertentu, baik penurunan atau kenaikan. Rasio ini dapat dilakukan dengan membandingkan berbagai komponen yang ada dalam laporan laba rugi perusahaan.

Analisis laporan keuangan bertujuan untuk mengetahui tingkat efektif dan efesiensi kinerja keuangan suatu perusahaan. Selain itu, analisis laporan keuangan juga digunakan sebagai tolok ukur bagi perusahaan untuk meningkatkan kinerja perusahaan tersebut serta untuk membandingkan kinerja keuangan setiap periode akuntansi.

Media yang dapat digunakan untuk menilai kinerja keuangan Perusahaan adalah Laporan Keuangan. Laporan Keuangan merupakan hasil pengumpulan dan pengolahan data keuangan yang disajikan dalam bentuk laporan keuangan atau ikhtisar lainnya sehingga dapat digunakan untuk menilai kinerja Perusahaan di dalam mengambil keputusan yang tepat dan akurat. 
Menurut Munawir (2014:2) Pengertian laporan keuangan adalah hasil dari proses akuntansi yang dapat digunakan sebagai alat untuk berkomunikasi antara data keuangan atau aktivitas suatu perusahaan dengan pihak-pihak yang berkepentingan dengan data atau aktivitas perusahaan tersebut.

Menurut Sutrisno (2013:9) laporan keuangan merupakan hasil akhir dari proses akuntansi yang meliputi dua laporan utama yakni Neraca dan laporan Rugi Laba. Menurut Myer dalam Munawir (2014:5) yang dimaksud dengan laporan keuangan adalah Dua daftar yang disusun oleh akuntan pada akhir periode untuk suatu perusahaan. Kedua daftar tersebut adalah daftar neraca atau posisi keuangan dan daftar pendapatan atau daftar laba rugi. Pada waktu akhir-akhir ini sudah menjadi kebiasaan bagi perseroan-perseroan untuk menambahkan daftar ketiga yaitu daftar surplus atau daftar laba yang tak dibagikan (laba yang ditahan).

Akuntansi yang dilaksanakan secara konsisten serta dibuat dan disajikan dalam bentuk neraca dan laporan laba rugi. Bentuk atau susunan neraca tidak ada keseragaman diantara perusahaan-perusahaan tergantung kepada tujuan-tujuan yang akan dicapai. Tetapi bentuk neraca yang umum digunakan (traditional atau conventional) menurut Munawir (2014:22) adalah sebagai berikut:

1. Bentuk skontro (acoount form) dimana semua aktiva tercantum sebelah kiri debet dan hutang serta modal tercantum sebelah kanan/kredit Munawir (2014:22). Contoh dari neraca yang berbentuk skontro ditampilkan pada Tabel 1.

Tabel 1. Bentuk Neraca Skontro

\begin{tabular}{lrlr}
\hline \multicolumn{1}{c}{ Uraian } & Jumlah & \multicolumn{1}{c}{ Uraian } & \multicolumn{1}{c}{ Jumlah } \\
AKTIVA & & KEWAJIBAN & \\
\hline AKTIVA LANCAR & & Hutang Usaha & 64.906 .550 \\
\hline Kas & 30.156 .000 & Hutang Bank & 114.906 .550 \\
\hline Bank Mandiri & 225.650 .000 & JUMLAH & \\
& & KEWAJIBAN & $\mathbf{1 7 9 . 8 1 3 . 1 0 0}$ \\
\hline Piutang Usaha & 83.088 .550 & & \\
\hline Jumlah Aktiva Lancar & $\mathbf{3 3 8 . 8 9 4 . 5 5 0}$ & & \\
\hline
\end{tabular}

AKTIVA TETAP

\begin{tabular}{lrlr}
\hline Tanah & 85.432 .000 & Modal & 55.000 .000 \\
\hline Bangunan & 75.000 .000 & Laba Berjalan & 187.996 .000 \\
\hline Inventaris Kantor & 14.748 .500 & Jumlah Ekuitas & $\mathbf{2 4 2 . 9 9 6 . 0 0 0}$ \\
\hline Kendaraan & 17.800 .000 & JUMLAH & \\
& & $\begin{array}{l}\text { KEWAJIBAN DAN } \\
\text { EKUITAS }\end{array}$ & $\mathbf{4 2 2 . 8 0 9 . 1 0 0}$ \\
& & &
\end{tabular}

Akum. Peny. Bangunan $\quad(70.000 .000)$

Akum. Peny. Inventaris (27.940.950)

Kantor

Akum. Peny. Kendaraan

Jumlah Aktiva Tetap

JUMLAH AKTIVA
83.914.550

422.809.100 
2. Bentuk Vertikal (stafet atau report form), adalah bentuk ini semua aktiva nampak dibagian atas yang selanjutnya diikuti dengan hutang jangka pendek, hutang jangka panjang serta modal bentuk neracanya ditunjukkan pada Tabel 2 .

Tabel 2. Bentuk Neraca Vertikal

\begin{tabular}{lr}
\hline URAIAN & JUMLAH \\
\hline AKTIVA & \\
\hline AKTIVA LANCAR & 30.156 .000 \\
\hline Kas & 225.650 .000 \\
\hline Bank Mandiri & 83.088 .550 \\
\hline Piutang Usaha & $\mathbf{3 3 8 . 8 9 4 . 5 5 0}$ \\
\hline Jumlah Aktiva Lancar & 85.432 .000 \\
\hline AKTIVA TETAP & 75.000 .000 \\
\hline Tanah & 14.748 .500 \\
\hline Bangunan & 17.800 .000 \\
\hline Inventaris Kantor & $(70.000 .000)$ \\
\hline Kendaraan & $(27.940 .950)$ \\
\hline Akum. Penyusutan Bangunan & $(11.125 .000)$ \\
\hline Akum. Penyusutan Inventaris Kantor & $\mathbf{8 3 . 9 1 4 . 5 5 0}$ \\
\hline Akum. Penyusutan Kendaraan & $\mathbf{4 2 2 . 8 0 9 . 1 0 0}$ \\
\hline Jumlah Aktiva Tetap & 64.906 .550 \\
\hline JUMLAH AKTIVA & 114.906 .550 \\
\hline KEWAJIBAN & $\mathbf{1 7 9 . 8 1 3 . 1 0 0}$ \\
\hline Hutang Usaha & \\
\hline Hutang Bank & $\mathbf{5 5 . 0 0 0 . 0 0 0}$ \\
\hline JUMLAH KEWAJIBAN & $\mathbf{2 4 2 . 9 9 6 . 0 0 0}$ \\
\hline EKUITAS & $\mathbf{4 2 2 . 8 0 9 . 1 0 0}$ \\
\hline Modal & \\
\hline Laba Berjalan & \\
\hline Jumlah Ekuitas & \\
\hline JUMLAH KEWAJIBAN DAN EKUITAS & \\
\hline
\end{tabular}

Menurut Munawir (2014:26) pengertian laporan laba rugi adalah sebagai berikut: "Laporan laba rugi merupakan suatu laporan yang sistematis tentang penghasilan, biaya laba rugi yang diperoleh oleh suatu perusahaan selama periode tertentu." Walaupun belum ada keseragaman tentang susunan laporan laba rugi tiap-tiap perusahaan, namun prinsip-prinsip yang umumnya diterapkan adalah sebagai berikut:

1. Bagian pertama yang menunjukkan penghasilan yang diperoleh dari usaha perusahaan (penjualan barang dagangan atau memberikan service) diikuti dengan harga pokok dari barang/service yang dijual, sehingga diperoleh laba kotor.

2. Bagian kedua menunjukkan biaya-biaya operasional yang terdiri dari biaya penjualan dan biaya umum/administrasi (operating expense).

3. Bagian ketiga menunjukkan hasil-hasil yang diperoleh diluar operasi pokok perusahaan, yang diikuti dengan biaya-biaya yang terjadi diluar usaha pokok perusahaan (non operating/financial imcome and expence). 
4. Bagian keempat menunjukkan laba tau rugi yang insidentil (extra ordinary gain or loss) sehingga akhirnya diperoleh laba bersih sebelum pajak pendapatan.

Menurut Munawir (2014:27) bentul laba rugi yang biasanya digunakan adalah sebagai berikut:

1. Bentuk Single Step yaitu dengan menggunakan semua penghasilan menjadi satu kelompok dan semua biaya dalam satu kelompok, sehingga untuk menghitung rugi laba bersih hanya memerlukan satu langkah yaitu mengurangkan total biaya terhadap total penghasilan. Contoh bentuk Single Step ditunjukkan pada Tabel 3.

Tabel 3. Laporan Laba Rugi Single Step

\begin{tabular}{|c|c|c|}
\hline URAIAN & & JUMLAH \\
\hline \multicolumn{3}{|l|}{ PENDAPATAN } \\
\hline Jumlah Pendapatan & & 250.381 .000 \\
\hline Jumlah Biaya Usaha & & 62.660 .000 \\
\hline \multicolumn{3}{|l|}{ PENDAPATAN KOMP. LAIN } \\
\hline Pendapatan Lain-lain Diluar Usaha & 650.000 & \\
\hline Biaya Lain-lain Diluar Usaha & $(375.000)$ & \\
\hline Jumlah & & 275.000 \\
\hline Laba Bersih & & 187.996 .000 \\
\hline
\end{tabular}

2. Bentuk Multiple Step yaitu pengelompokkan dilakukan dengan prinsip yang umum. Dalam bentuk ini dilakukan yang lebih teliti dengan prinsip yang digunakan secara umum, bentuk tersebut ditunjukkan pada Tabel 4.

Tabel 4. Laporan Laba Rugi Multi Step

\begin{tabular}{lrr}
\hline URAIAN & & JUMLAH \\
\hline PENDAPATAN & & 250.381 .000 \\
\hline Jumlah Pendapatan & & \\
\hline BIAYA USAHA & 45.900 .000 & \\
\hline Gaji & 1.500 .000 & \\
\hline Alat Tulis Kantor & 5.500 .000 & \\
\hline Transport / Perjalanan Dinas & 1.750 .000 & \\
\hline Listrik, Air \& Telpon & 860.000 & 62.660 .000 \\
\hline Biaya Penyusutan & 350.000 & \\
\hline Biaya Pemeliharaan & 5.400 .000 & \\
\hline Komisi Guide & 950.000 & \\
\hline Biaya Konsumsi Karyawan & 450.000 & \\
\hline Biaya Usaha Lainnya & & 187.996 .000 \\
\hline Jumlah Biaya Usaha & 650.000 & $(375.000)$ \\
\hline PENDAPATAN KOMP. LAIN & & \\
\hline Pendapatan Lain-lain Diluar Usaha & & \\
\hline Biaya Lain-lain Diluar Usaha & & \\
\hline Jumlah & & \\
\hline Laba Bersih & & \\
\hline
\end{tabular}


Laporan keuangan merupakan alat yang sangat penting untuk memperoleh informasi sehubungan dengan posisi keuangan dan hasil-hasilnya yang telah dicapai oleh perusahaan yang bersangkutan. Melalui laporan keuangan yang dimaksud untuk memberikan informasi kuantitatif mengenai keadaan keuangan perusahaan tersebut pada suatu periode baik untuk kepentingan manajer, pemilik perusahaan, digunakan dalam berbagai bentuk analisis.

Menurut Prihadi (2013:1) mendefinisikan rasio keuangan adalah rasio keuangan adalah indeks yang menghubungkan dua angka akuntansi dan diperoleh dengan membagi satu angka dengan angka yang lainnya. Menurut Harahap (2013:297) menyatakan rasio keuangan adalah angka yang diperoleh dari hasil perbandingan dari suatu laporan keuangan dengan laporan yang lainnya yang mempunyai hubungan relevan dan signifikan misalnya antara utang dan modal, antara kas dan total asset, antara harga pokok produksi dengan total penjualan dan sebagainya. Menurut Muslich (2013:44) menyatakan bahwa analisis rasio keuangan merupakan alat utama dalam analisis keuangan, karena analisis ini dapat digunakan untuk menjawab berbagai pertanyaan tentang keadaan perusahaan. Sedangkan menurut Jumingan (2016:44) menyatakan bahwa analisis rasio keuangan merupakan alat utama dalam menganalisis keuangan, karena analisis ini dapat digunakan untuk menjawab berbagai pertanyaan tentang keadaan keuangan perusahaan.

Dalam mengevaluasi kondisi keuangan perusahaan dan kinerjanya, analisis keuangan perlu melakukan pemeriksaan atas berbagai aspek kesehatan keuangan perusahaan. Dengan menggunakan alat analisis laporan keuangan, terutama bagi pemilik usaha dan manajemen, dapat diketahui berbagai hal yang berkaitan dengan keuangan dan kemajuan perusahaan. Alat yang sering digunakan selama pemeriksaan adalah rasio keuangan. Adapun bentuk-bentuk rasio keuangan adalah sebagai berikut:

1. Rasio Likuiditas

Rasio likuiditas menurut Weston yang dikutip oleh Kasmir (2015:129) menyatakan bahwa, "Rasio likuiditas (liquidity ratio) merupakan rasio yang menggambarkan kemampuan perusahaan dalam memenuhi kewajiban (utang) jangka pendek."Rasio likuiditas Menurut Wild (2012:9) menyatakan bahwa Rasio likuiditas (liquidity) merupakan kemampuan perusahaan untuk menghasilkan kas dalam jangka pendek untuk memenuhi kewajibannya.Jenis-jenis rasio likuiditas yang digunakan perusahaan, yaitu:

a. Current Ratio

Current Ratio menurut Sujarweni (2015:26) adalah rasio lancar menunjukkan kemampuan perusahaan untuk membayar kewajiban jangka pendeknya dengan menggunakan aktiva lancar. Formula untuk mengetahui rasio ini sebagai berikut:

\section{Current Ratio $=\frac{\text { Aktiva Lancar }}{\text { Hutang Lancar }}$}

b. Quick Ratio

Quick Ratio menurut Sujarweni (2015:26) adalah rasio yang menunjukkan kemampuan perusahaan dalam memenuhi atau membayar kewajiban atau utang lancar (utang jangka pendek) dengan aktiva lancar tanpa memperhitungkan nilai sediaan (inventory). Rumusan untuk mencari rasio cepat sebagai berikut:

Quick Ratio $=\frac{\text { Aktiva Lancar }- \text { Persediaan }}{\text { Kewajiban Jangka Pendek }}$ 
c. Rasio Kas (Cash Ratio)

Menurut Sugiono (2013:62), rasio kas adalah "Rasio yang merupakan perbandingan antara kas yang ada di perusahaan dibandingkan dengan total utang lancar."Pendapat yang hampir sama diungkapkan oleh Kasmir (2015:139) bahwa, "Rasio kas (Cash Ratio) merupakan alat yang digunakan untuk mengukur seberapa besar uang kas yang tersedia untuk membayar utang." Formula untuk menghitung rasio kas adalah:

$$
\text { Rasio Kas }=\frac{\text { Kas }}{\text { Kewajiban Lancar }} \times 100 \%
$$

2. Rasio Solvabilitas

Rasio solvabilitas menurut Wild (2012:9) merupakan kemungkinan dan kemampuan jangka panjang perusahaan untuk melunasi kewajiban jangka panjang. Rasio ini digunakan untuk mengukur kemampuan perusahaan untuk membayar seluruh kewajibannya, baik jangka pendek maupun jangka panjang apabila perusahaan dilikuidasi. Jenis-jenis rasio solvabilitas menurut Horne (2014:208), adalah sebagai berikut:

a. Rasio Utang (Debt Ratio)

Rasio utang merupakan rasio yang digunakan untuk mengukur perbandingan antara total utang dan total aktiva. Dengan kata lain, rasio utang mengukur seberapa besar aktiva perusahaan dibiayai oleh utang atau seberapa besar utang perusahaan berpengaruh terhadap pengelolaan aktiva. Rumus untuk mencari debt ratio sebagai berikut:

$$
\text { Rasio Utang }=\frac{\text { Total Utang }}{\text { Total Aktiva }} \times 100 \%
$$

b. Rasio Utang terhadap Ekuitas (Debt to Eqiuty Ratio)

Perputaran utang terhadap ekiutas adalah rasio yang diinginkan untuk menilai utang dengan ekuitas. Persamaan untuk mencari rasio ini sebagai berikut:

$$
\text { Rasio Utang terhadap Ekuitas }=\frac{\text { Total Utang }}{\text { Ekuitas }}
$$

\section{Catatan :}

Semakin tinggi nilai persentase rasio solvabilitas ini adalah semakin buruk kemampuan perusahaan untuk membayar kewajiban jangka panjangnya, maksimal nilainya adalah $200 \%$.

\section{Rasio Aktivitas}

Jenis-jenis rasio aktivitas yang sering digunakan, yaitu:

a. Perputaran Piutang (receivable turn over)

Perputaran piutang merupakan rasio yang digunakan untuk mengukur berapa lama penagihan piutang selama satu periode atau berapa kali dana yang diinvestasikan dalam piutang ini berputar dalam satu periode. Rumus untuk mencari receivable turn over adalah sebagai berikut:

$$
\text { Perputaran Piutang }=\frac{\text { Penjualan Kredit }}{\text { Piutang }}
$$


b. Perputaran Total Aktiva (Total Asset Turnover)

Total Asset Turnover merupakan rasio yang digunakan untuk mengukur perputaran semua aktiva yang dimiliki perusahaan, mengukur berapa jumlah penjualan dari tiap rupiah aktiva. Persamaan untuk mencari rasio tersebut adalah sebagai beikut:

\section{Total asset turnover $=\frac{\text { Penjualan }}{\text { Total Aktiva }}$}

c. Perputaran persediaan

Perputaran persediaan merupakan rasio yang digunakan untuk mengukur berapa kali dana yang diinvestasikan dalam persediaan (inventory) ini berputar dalam satu periode. Dari pengertian di atas, dapat dikatakan bahwa rasio perputaran persediaan merupakan rasio yang menunjukkan berapa kali jumlah barang sediaan diganti dalam satu tahun. Rumus untuk mencari inventory turn over dapat digunakan dengan dua cara yang dikutip oleh Kasmir (2015:180) sebagai berikut:

1) Menurut James Horne:

$$
\text { Inventory turn over }=\frac{\text { Harga pokok barang yang dijual }}{\text { Persediaan }}
$$

2) Menurut J Fred Weston:

$$
\text { Inventory turn over }=\frac{\text { Penjualan }}{\text { Persediaan }}
$$

\section{Catatan:}

Semakin tinggi nilai persentase rasio ini adalah semakin baik. Perusahaan bisa membandingkannya dengan nilai rata-rata dari industri sejenis di pasar agar dapat menilai efisien perusahaan mengelola sumber daya yang dimiliki.

4. Rasio Profitabilitas

Jenis-jenis rasio profitabilitas yang dapat digunakan adalah:

a. Margin laba (profit margin)

Margin laba adalah rasio yang membandingkan laba bersih setelah pajak dengan penjualan bersih. Margin laba kotor menunjukkan laba yang relatif terhadap perusahaan. Sedangkan, margin laba bersih merupakan ukuran keuntungan dengan membandingkan antara laba setelah bunga dan pajak dibandingkan dengan penjualan. Untuk menghitung margin laba, digunakan dua persamaan sebagai berikut:

1) Untuk margin laba kotor :

$$
\text { Margin laba kotor }=\frac{\text { Penjualan Bersih }- \text { Harga pokok penjualan }}{\text { Penjualan bersih }}
$$

2) Untuk margin laba bersih:

$$
\text { Margin laba bersih }=\frac{\text { Laba setelah Bunga dan Pajak }(\text { EAT })}{\text { Penjualan bersih }}
$$


b. Return on Asset (ROA)

Return on invesment (ROA) merupakan rasio yang menunjukkan hasil (return) atas jumlah aktiva yang digunakan dalam perusahaan. ROA juga merupakan suatu ukuran tentang efektivitas manajemen dalam mengelola investasinya. Rumus untuk mencari Return on Asset (ROA) dapat digunakan sebagai berikut:

\section{ROA $=\frac{\text { Laba setelah Bunga dan Pajak }}{\text { Total Aktiva }}$}

Atau dapat pula dihitung dengan menggunakan pendekatan Du Pont sebagai berikut:

\section{ROA = Margin laba bersih $x$ Perputaran total aktiva}

c. Return on Eqiuty (ROE)

Tingkat pengembalian atas ekuitas (ROE) merupakan rasio untuk mengukur laba bersih sesudah pajak dengan modal sendiri. Rasio ini menunjukkan efesiensi penggunaan modal sendiri. Semakin tinggi rasionya, maka semakin baik/posisi pemilik perusahaan. Formula untuk mencari return on equity yang digunakan oleh perusahaan adalah:

$$
\mathrm{ROE}=\frac{\text { Laba setelah Bunga dan Pajak }}{\text { Ekuitas }}
$$

Atau dapat pula dihitung dengan menggunakan pendekatan Du Pont sebagai berikut:

\section{ROE = Margin Laba Bersih X Perputaran Total Aktiva X Pengganda Ekuitas}

\section{Catatan:}

Tinggi nilai persentase rasio profitabilitas ini adalah semakin tinggi semakin baik.

\section{Metode Penelitian}

Penelitian ini adalah metode penelitian deskriptif yaitu penelitian yang dilakukan untuk memberikan gambaran yang lebih lengkap mengenai suatu fenomena, baik itu fenomena yang sedang berlangsung maupun fenomena yang sudah terjadi di masa lalu (Zagladi, 2017:32). Jenis data dalam penelitian ini adalah:

1. Data Kuantitatif

Adalah data yang diwujudkan dalam angka-angka yang menggambarkan statistik operasional atau keadaan perusahaan. Data yang dimaksud adalah laporan keuangan perusahaan meliputi Neraca dan Laporan Laba/Rugi.

2. Data Kualitatif

Adalah data yang tidak diwujudkan dalam angka-angka melainkan penjelasan yang menggambarkan keadaan perusahaan. Meliputi: struktur organisasi, sistem wewenang perusahaan serta yang berhubungan dengan perusahaan dan data tentang kebijakan akuntansi keuangan yang diterapkan oleh perusahaan serta struktur organisasi perusahaan

Jenis data dalam penelitian ini adalah data primer yang diambil langsung dari lapangna, dan data sekunder yang diambil dari sumber lain. 
Teknik pengumpulan data yang dilakukan dalam penelitian ini, yaitu :

1. Teknik Kepustakaan yaitu penelitian yang dilakukan dengan cara mengumpulkan data-data dan bahan-bahan dari beberapa literatur yang ada hubungannya dengan permasalahan yang dibahas terhadap kinerja keuangan.

2. Teknik Lapangan yaitu penelitian yang dilakukan dengan datang ke objek penelitian untuk melakukan pengamatan dan meminta data yang diperlukan misalnya gambaran umum objek penelitian dan laporan keuangan yang dimiliki dengan cara pengamatan yaitu pengumpulan data yang dilakukan dengan mengamati secara langsung pada objek yang diteliti, wawancara yaitu mengumpulkan informasi dengan media tanya jawab secara langsung dengan bagian keuangan perusahaan, dan dokumentasi yaitu teknik mengumpulkan, meneliti, mempelajari dokumen, catatan dan laporan-laporan yang berhubungan dengan masalah yang akan diteliti dari dokumen-dokumen yang dimiliki oleh perusahaan.

\section{Hasil Penelitian dan Pembahasan}

Untuk menilai kinerja keuangan pada PT. Kapuas Tata Steel Banjarbaru, maka dapat disajikan data hasil penelitian yang diperoleh pada Tabel 5 dan 6.

Tabel 5. PT. Kapuas Tata Steel Banjarbaru Laporan Posisi Keuangan Yang Berakhir Per 31 Desember Tahun 2013-2017 (Disajikan Dalam Puluhan Rupiah)

\begin{tabular}{|c|c|c|c|c|c|}
\hline Uraian & 2013 & 2014 & 2015 & 2016 & 2017 \\
\hline \multicolumn{6}{|l|}{ ASET } \\
\hline \multicolumn{6}{|l|}{ Aset Lancar } \\
\hline Kas & 8.150 .000 & 7.220 .000 & 9.530 .000 & 7.840 .000 & 5.400 .000 \\
\hline Bank & 10.000 .000 & 10.542 .000 & 9.550 .000 & 11.290 .500 & 10.880 .000 \\
\hline Piutang Usaha & 15.000 .000 & 13.550 .000 & 18.430 .500 & 10.930 .000 & 11.850 .000 \\
\hline Piutang Lain-Lain & 2.208 .950 & 2.308 .950 & 2.194 .500 & 3.150 .800 & 3.050 .000 \\
\hline Persediaan & 16.750 .000 & 17.200 .000 & 18.300 .000 & 15.488 .000 & 16.920 .500 \\
\hline Uang Muka dan Beban Dibayar Dimuka & 2.200 .000 & 2.600 .000 & 4.850 .000 & 2.150 .000 & 2.750 .000 \\
\hline Jumlah Aset Lancar & 54.308.950 & $\mathbf{5 3 . 4 2 0 . 9 5 0}$ & 62.855.000 & $\mathbf{5 0 . 8 4 9 . 3 0 0}$ & $\mathbf{5 0 . 8 5 0 . 5 0 0}$ \\
\hline \multicolumn{6}{|l|}{ Aset Tetap } \\
\hline Tanah & 100.600 .000 & 100.600 .000 & 100.600 .000 & 100.600 .000 & 100.600 .000 \\
\hline Bangunan & 15.900 .800 & 15.900 .800 & 15.900 .800 & 16.190 .000 & 16.190 .000 \\
\hline Mesin & 35.000 .000 & 35.000 .000 & 44.000 .000 & 95.780 .000 & 65.780 .000 \\
\hline Kendaraan & 8.500 .000 & 8.500 .000 & 7.350 .000 & 7.350 .000 & 8.115 .000 \\
\hline Inventaris & 125.500 & 113.800 & 119.500 & 128.900 & 135.660 \\
\hline Akumulasi Penyusutan & $(78.945 .320)$ & $(81.867 .070)$ & $(110.650 .344)$ & $(113.455 .755)$ & $(115.359 .895)$ \\
\hline h Aset Tetap & 81.180 .980 & 78.247.530 & $\mathbf{5 7 . 3 1 9 . 9 5 6}$ & 106.593 .145 & 75.460 .765 \\
\hline JUMLAH ASET & 135.489 .930 & 131.668.480 & 120.174 .956 & 157.442 .445 & 126.311.265 \\
\hline \multicolumn{6}{|l|}{ KEWAJIBAN DAN EKUITAS } \\
\hline \multicolumn{6}{|l|}{ KEWAJIBAN } \\
\hline \multicolumn{6}{|l|}{ Kewajiban Jangka Pendek } \\
\hline Hutang Usaha & 26.904 .250 & 23.307 .100 & 15.455 .600 & 25.660 .800 & 21.964 .000 \\
\hline Hutang Pajak & 632.300 & 733.250 & 835.040 & 10.530 .700 & 9.954 .000 \\
\hline Hutang Bank Jangka Pendek & 12.500 .000 & 12.000 .000 & 9.500 .000 & 11.000 .000 & 10.500 .000 \\
\hline Jumlah Kewajiban Jangka Pendek & 40.036.550 & 36.040.350 & 25.790 .640 & 47.191.500 & $\overline{42.418 .000}$ \\
\hline \multicolumn{6}{|l|}{ Kewajiban Jangka Panjang } \\
\hline Hutang Bank Jangka Panjang & 40.000 .000 & 42.000 .000 & 45.500 .000 & 59.150 .000 & 41.800 .000 \\
\hline Hutang Sewa Pembiayaan & 6.500 .000 & 6.000 .000 & 5.500 .000 & 8.000 .000 & 4.500 .000 \\
\hline Jumlah Kewajiban Jangka Panjang & 46.500 .000 & 48.000.000 & 51.000 .000 & 67.150 .000 & 46.300.000 \\
\hline JUMLAH KEWAJIBAN & 86.536 .550 & 84.040 .350 & 76.790 .640 & 114.341 .500 & 88.718 .000 \\
\hline \multicolumn{6}{|l|}{ EKUITAS } \\
\hline Modal & 40.960 .630 & 40.960 .630 & 37.388 .816 & 31.239 .905 & 24.229 .265 \\
\hline Saldo Laba & 7.992 .750 & 6.667 .500 & 5.995 .500 & 11.861 .040 & 13.364 .000 \\
\hline JUMLAH EKUITAS & 48.953.380 & 47.628.130 & 43.384.316 & 43.100 .945 & 37.593.265 \\
\hline $\begin{array}{l}\text { JUMLAH KEWAJIBAN DAN } \\
\text { EKUITAS }\end{array}$ & 135.489 .930 & 131.668 .480 & 120.174 .956 & $\mathbf{1 5 7 . 4 4 2 . 4 4 5}$ & 126.311 .265 \\
\hline
\end{tabular}


Tabel 6. PT. Kapuas Tata Steel Banjarbaru Laporan Laba Rugi dan Penghasilan Komprehensif Lain Yang Periode Yang Berakhir Per 31 Desember Tahun 2013-2017 (Disajikan Dalam Puluhan Rupiah)

\begin{tabular}{|c|c|c|c|c|c|}
\hline+++ & 2013 & 2014 & 2015 & 2016 & 2017 \\
\hline Pendapatan & 179.000 .000 & 155.000 .000 & 203.000 .000 & 187.650 .000 & 195.230 .000 \\
\hline Beban Pokok Pendapatan & $(135.000 .000)$ & $(115.000 .000)$ & $(157.500 .000)$ & $(142.800 .000)$ & $(138.950 .000)$ \\
\hline LABA BRUTO & 44.000 .000 & 40.000 .000 & 45.500 .000 & 44.850 .000 & 56.280 .000 \\
\hline \multicolumn{6}{|l|}{ BEBAN USAHA } \\
\hline Penghasilan Lain & 2.550 .000 & 2.355 .000 & 1.789 .000 & 2.528 .000 & 2.110 .000 \\
\hline Beban Penjualan & $(12.900 .000)$ & $(12.380 .000)$ & $(13.750 .000)$ & $(9.230 .000)$ & $(14.540 .000)$ \\
\hline Beban Administrasi dan Umum & $(18.643 .000)$ & $(16.935 .000)$ & $(18.345 .000)$ & $(17.220 .000)$ & $(16.750 .000)$ \\
\hline Beban Keuangan Netto & $(4.000 .000)$ & $(3.500 .000)$ & $(6.500 .000)$ & $(4.150 .000)$ & $(5.980 .000)$ \\
\hline Beban Pajak Final & $(350.000)$ & $(650.000)$ & $(700.000)$ & $(530.000)$ & $(560.000)$ \\
\hline $\begin{array}{l}\text { LABA SEBELUM PAJAK } \\
\text { PENGHASILAN }\end{array}$ & 10.657 .000 & 8.890 .000 & $\overline{7.994 .000}$ & 16.248 .000 & 20.560 .000 \\
\hline Beban Pajak Penghasilan & 2.664 .250 & 2.222 .500 & 1.998 .500 & 4.386 .960 & 7.196 .000 \\
\hline LABA TAHUN BERJALAN & 7.992 .750 & 6.667 .500 & 5.995 .500 & 11.861 .040 & 13.364 .000 \\
\hline \multicolumn{6}{|l|}{$\begin{array}{l}\text { PENGHASILAN } \\
\text { KOMPREHENSIF LAIN } \\
\end{array}$} \\
\hline \multicolumn{6}{|l|}{$\begin{array}{l}\text { Pos-pos yang tidak direklasifikasi ke } \\
\text { laba rugi }\end{array}$} \\
\hline $\begin{array}{l}\text { Keuntungan (Kerugian) aktuarial- } \\
\text { imbalan kerja }\end{array}$ & 700.000 & $(872.100)$ & 855.000 & 733.000 & $(645.800)$ \\
\hline Pajak penghasilan terkait pos yang & $(175.000)$ & 218.025 & $(215.000)$ & $(165.400)$ & 319.035 \\
\hline $\begin{array}{l}\text { tidak akan direklasifikasi ke laba rugi } \\
\text { atas program imbalan pasti }\end{array}$ & & & & & \\
\hline $\begin{array}{l}\text { JUMLAH LABA } \\
\text { KOMPREHENSIF TAHUN } \\
\text { BERJALAN }\end{array}$ & 8.517 .750 & 6.013 .425 & 6.635 .500 & 12.428 .640 & 13.037 .235 \\
\hline
\end{tabular}

Berdasarkan laporan keuangan PT. Kapuas Tata Steel Banjarbaru, maka dapat disajikan perbandingannya seperti ditampilkan pada Tabel 7 dan 8.. Perhitungan untuk masing-masing rasio keuangan adalah sebagai berikut:

1. Rasio Likuiditas

Rasio likuiditas digunakan untuk menggambarkan perusahaan dalam menyelesaikan kewajiban jangka pendeknya. Rasio ini dapat dihitung melalui sumber informasi yaitu pada pos-pos aset lancar dan hutang lancar, maka peneliti dapat menganalisis hal-hal sebagai berikut:

a. Rasio Lancar (Current Ratio)

Rumus untuk menghitung rasio lancar adalah sebagai berikut:

Rasio Lancar $=\underset{\text { Hutang Lancar }}{\text { Aset Lancar }}$ X 100\%

Perhitungan rasio lancar pada PT. Kapuas Tata Steel Banjarbaru untuk tahun 2013, 2014, 2015, 2016 dan 2017 adalah sebagai berikut:

Tahun 2013

Rasio Lancar $=\frac{54.308 .950}{40.036 .550}=1,2 \mathrm{kali}$

Artinya :

Setiap Rp. 1,00 hutang lancar akan dijamin dengan aset lancar sebesar Rp. 1,2,-. 
Tabel 7. Daftar Nilai Neraca Perbandingan PT. Kapuas Tata Steel Banjarbaru Tahun 2013-2017

\begin{tabular}{|c|c|c|c|c|c|c|c|c|}
\hline \multirow[t]{2}{*}{ Uraian } & \multicolumn{2}{|c|}{ Selisih (2013-2014) } & \multicolumn{2}{|c|}{ Selisih (2014-2015) } & \multicolumn{2}{|c|}{ Selisih (2015-2016) } & \multicolumn{2}{|c|}{ Selisih (2016-2017) } \\
\hline & $\mathbf{R p}$ & $\%$ & $\mathbf{R p}$ & $\%$ & Rp & $\%$ & $\mathbf{R p}$ & $\%$ \\
\hline \multicolumn{9}{|l|}{ ASET } \\
\hline \multicolumn{9}{|l|}{ Aset Lancar } \\
\hline \multirow[t]{2}{*}{ Kas } & & $-0,11$ & & 0,32 & & $-0,18$ & & $-0,31$ \\
\hline & $(930.000)$ & & 2.310 .000 & & $(1.690 .000)$ & & $(2.440 .000)$ & \\
\hline Bank & 542.000 & 0,05 & $(992.000)$ & $-0,09$ & 1.740 .500 & 0,18 & $(410.500)$ & $-0,04$ \\
\hline Piutang Usaha & $(1.450 .000)$ & $-0,10$ & 4.880 .500 & 0,36 & $(7.500 .500)$ & $-0,41$ & 920.000 & 0,08 \\
\hline Piutang Lain-Lain & 100.000 & 0,05 & $(114.450)$ & $-0,05$ & 956.300 & 0,44 & $(100.800)$ & $-0,03$ \\
\hline Persediaan & 450.000 & 0,03 & 1.100 .000 & 0,06 & $(2.812 .000)$ & $-0,15$ & 1.432 .500 & 0,09 \\
\hline $\begin{array}{l}\text { Uang Muka dan Beban Dibayar } \\
\text { Dimuka }\end{array}$ & 400.000 & 0,18 & 2.250 .000 & 0,87 & $(2.700 .000)$ & $-0,56$ & 600.000 & 0,28 \\
\hline Jumlah Aset Lancar & $(888.000)$ & $-0,02$ & 9.434 .050 & 0,18 & $(12.005 .700)$ & $-0,19$ & 1.200 & 0,00 \\
\hline \multicolumn{9}{|l|}{ Aset Tetap } \\
\hline Tanah & - & 0,00 & - & 0,00 & - & 0,00 & - & 0,00 \\
\hline Bangunan & - & 0,00 & - & 0,00 & 289.200 & 0,02 & - & 0,00 \\
\hline Mesin & - & 0,00 & 9.000 .000 & 0,26 & 51.780 .000 & 1,18 & $(30.000 .000)$ & $-0,31$ \\
\hline Kendaraan & - & 0,00 & $(1.150 .000)$ & $-0,14$ & - & 0,00 & 765.000 & 0,10 \\
\hline Inventaris & $(11.700)$ & $-0,09$ & 5.700 & 0,05 & 9.400 & 0,08 & 6.760 & 0,05 \\
\hline Akumulasi Penyusutan & $(2.921 .750)$ & 0,04 & $(28.783 .274)$ & 0,35 & $(2.805 .411)$ & 0,03 & $(1.904 .140)$ & 0,02 \\
\hline Jumlah Aset Tetap & $(2.933 .450)$ & $-0,04$ & $(20.927 .574)$ & $-0,27$ & 49.273 .189 & 0,86 & $(31.132 .380)$ & $-0,29$ \\
\hline JUMLAH ASET & $(3.821 .450)$ & $-0,03$ & $(11.493 .524)$ & $-0,09$ & 37.267 .489 & 0,31 & $(31.131 .180)$ & $-0,20$ \\
\hline \multicolumn{9}{|l|}{ KEWAJIBAN DAN EKUITAS } \\
\hline \multicolumn{9}{|l|}{ KEWAJIBAN } \\
\hline \multicolumn{9}{|l|}{ Kewajiban Jangka Pendek } \\
\hline Hutang Usaha & $(3.597 .150)$ & $-0,13$ & $(7.851 .500)$ & $-0,34$ & 10.205 .200 & 0,66 & $(3.696 .800)$ & $-0,14$ \\
\hline Hutang Pajak & 100.950 & 0,16 & 101.790 & 0,14 & 9.695 .660 & 11,61 & $(576.700)$ & $-0,05$ \\
\hline Hutang Bank Jangka Pendek & $(500.000)$ & $-0,04$ & $(2.500 .000)$ & $-0,21$ & 1.500 .000 & 0,16 & $(500.000)$ & $-0,05$ \\
\hline $\begin{array}{l}\text { Jumlah Kewajiban Jangka } \\
\text { Pendek }\end{array}$ & $(3.996 .200)$ & $-0,10$ & $(10.249 .710)$ & $-0,28$ & 21.400 .860 & 0,83 & $(4.773 .500)$ & $-0,10$ \\
\hline \multicolumn{9}{|l|}{ Kewajiban Jangka Panjang } \\
\hline Hutang Bank Jangka Panjang & 2.000 .000 & 0,05 & 3.500 .000 & 0,08 & 13.650 .000 & 0,30 & $(17.350 .000)$ & $-0,29$ \\
\hline Hutang Sewa Pembiayaan & $(500.000)$ & $-0,08$ & $(500.000)$ & $-0,08$ & 2.500 .000 & 0,45 & $(3.500 .000)$ & $-0,44$ \\
\hline Jumlah Kewajiban Jangka & & 0,03 & & 0,06 & 16.150 .000 & 0,32 & & $-0,31$ \\
\hline Panjang & 1.500 .000 & & 3.000 .000 & & & & $(20.850 .000)$ & \\
\hline JUMLAH KEWAJIBAN & $(2.496 .200)$ & $-0,03$ & $(7.249 .710)$ & $-0,09$ & 37.550 .860 & 0,49 & $(25.623 .500)$ & $-0,22$ \\
\hline \multicolumn{9}{|l|}{ EKUITAS } \\
\hline Modal & - & 0,00 & $(3.571 .814)$ & $-0,09$ & $(6.148 .911)$ & $-0,16$ & $(7.010 .640)$ & $-0,22$ \\
\hline Saldo Laba & $(1.325 .250)$ & $-0,17$ & $(672.000)$ & $-0,10$ & 5.865 .540 & 0,98 & 1.502 .960 & 0,13 \\
\hline JUMLAH EKUITAS & $(1.325 .250)$ & $-0,03$ & $(4.243 .814)$ & $-0,09$ & $(283.371)$ & $-0,01$ & $(5.507 .680)$ & $-0,13$ \\
\hline $\begin{array}{l}\text { JUMLAH KEWAJIBAN DAN } \\
\text { EKUITAS }\end{array}$ & $(3.821 .450)$ & $-0,03$ & $(11.493 .524)$ & $-0,09$ & 37.267 .489 & 0,31 & $(31.131 .180)$ & $-0,20$ \\
\hline
\end{tabular}

Tahun 2014

Rasio Lancar $=\frac{53.420 .950}{36.040 .350}=1,5 \mathrm{kali}$

Artinya:

Setiap Rp. 1,00 hutang lancar akan dijamin dengan aset lancar sebesar Rp. 1,5,-.

$\underline{\text { Tahun } 2015}$

Rasio Lancar $=\frac{62.855 .000}{25.790 .640}=2,5 \mathrm{kali}$

Artinya:

Setiap Rp. 1,00 hutang lancar akan dijamin dengan aset lancar sebesar Rp. 2,5,-. 
Tabel 8. Daftar Nilai Laporan Laba Rugi dan Penghasilan Komprehensif Lain Perbandingan PT. Kapuas Tata Steel Banjarbaru Tahun 2013-2017

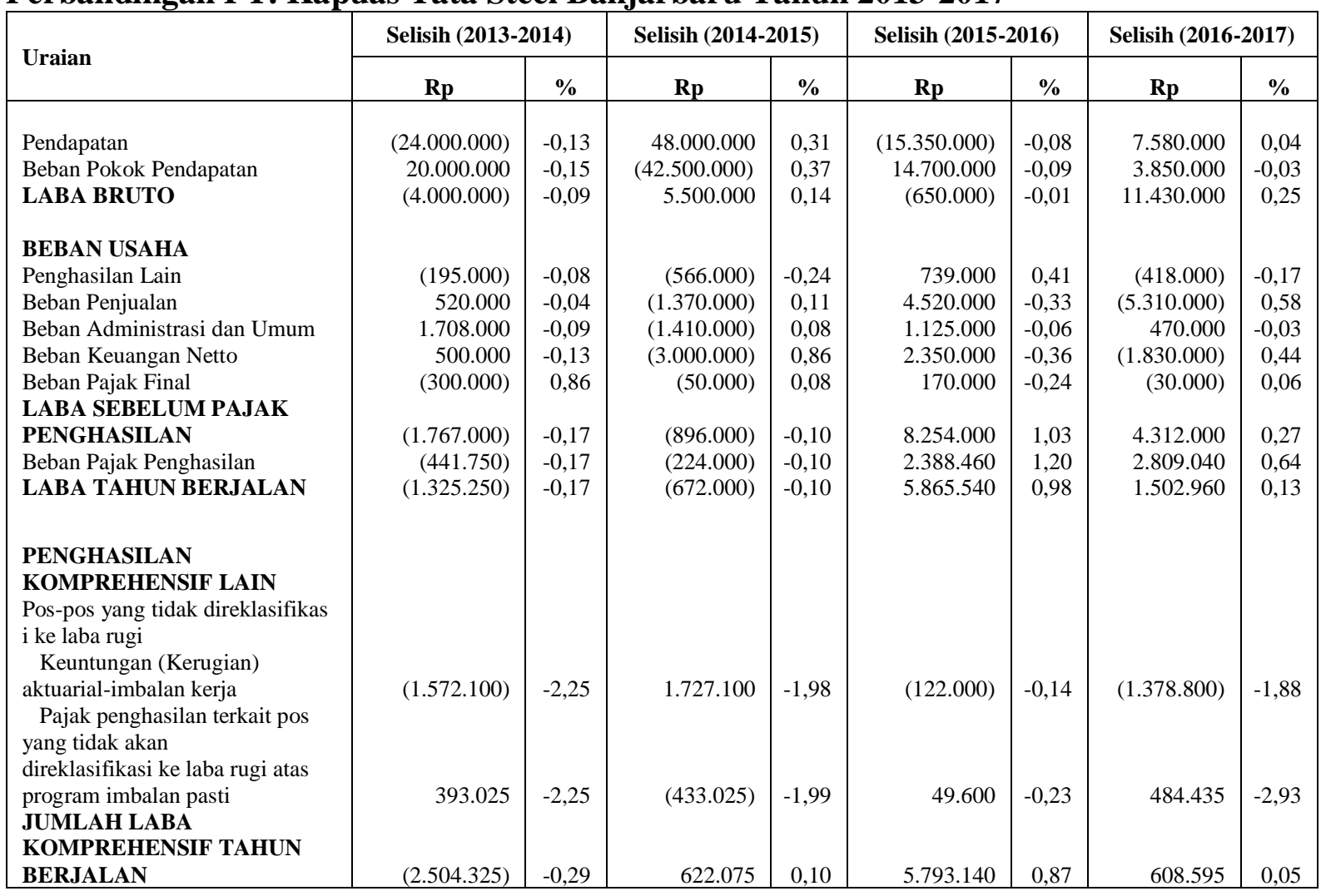

$\underline{\text { Tahun } 2016}$

Rasio Lancar $=\frac{50.849 .300}{47.191 .500}=1,1 \mathrm{kali}$

Artinya:

Setiap Rp. 1,00 hutang lancar akan dijamin dengan aset lancar sebesar Rp. 1,1,-.

$\underline{\text { Tahun } 2017}$

Rasio Lancar $=\frac{50.850 .500}{42.418 .000}=1,2 \mathrm{kali}$

Artinya:

Setiap Rp. 1,00 hutang lancar akan dijamin dengan aset lancar sebesar Rp. 1,2,-.

b. Rasio Cepat (Quick Ratio)

Rumus untuk menghitung rasio cepat adalah sebagai berikut:

Rasio Cepat $=\frac{\text { Aset Lancar }- \text { Persediaan }}{\text { Hutang Lancar }}$

Perhitungan rasio cepat pada PT. Kapuas Tata Steel Banjarbaru untuk tahun 2013, 2014, 2015, 2016 dan 2017 adalah sebagai berikut: 
$\underline{\text { Tahun } 2013}$

Rasio Cepat $=\frac{54.308 .950-16.750 .000}{40.036 .550}=0,94 \mathrm{kali}$

Artinya:

Setiap Rp 1,00 hutang lancar dijamin dengan Rp. 0,94 aset lancar dikurangi persediaan.

Tahun 2014

Rasio Cepat $=\frac{53.420 .950-17.200 .000}{36.040 .350}=1,01 \mathrm{kali}$

Artinya:

Setiap Rp 1,00 hutang lancar dijamin dengan Rp 1,01 aset lancar dikurangi persediaan.

$\underline{\text { Tahun } 2015}$

Rasio Cepat $=\frac{62.855 .000-18.300 .000}{25.790 .640}=1,73 \mathrm{kali}$

Artinya:

Setiap Rp 1,00 hutang lancar dijamin dengan Rp 1,73 aset lancar dikurangi persediaan.

$\underline{\text { Tahun } 2016}$

Rasio Cepat $=\frac{54 \cdot 308.950-15 \cdot 488.000}{47 \cdot 191 \cdot 500}=0,75 \mathrm{kali}$

Artinya:

Setiap Rp 1,00 hutang lancar dijamin dengan Rp 0,75 aset lancar dikurangi persediaan.

$\underline{\text { Tahun } 2017}$

Rasio Cepat $=\frac{50.850 .500-16.920 .000}{42.418 .000}=0,80 \mathrm{kali}$

Artinya:

Setiap Rp 1,00 hutang lancar dijamin dengan Rp 0,80 aset lancar dikurangi persediaan.

c. Rasio Kas (Cash Ratio)

Rumus untuk menghitung rasio kas adalah sebagai berikut:

Rasio Kas $=\underset{\text { Hutang Lancar }}{\text { Kas }+ \text { Bank }} \quad \mathrm{X} 100 \%$

Perhitungan rasio kas pada PT. Kapuas Tata Steel Banjarbaru untuk tahun 2013, 2014, 2015, 2016 dan 2017 adalah sebagai berikut:

$\underline{\text { Tahun } 2013}$

Rasio Kas $=\frac{8.150 .000+10.000 .000}{40.036 .550} \times 100 \%=45 \%$ 
Artinya:

Setiap Rp. 1,00 hutang lancar akan dijamin dengan kas dan bank sebesar Rp. 0,45,-.

Tahun 2014

Rasio Kas $=\frac{7.220 .000+10.542 .000}{36.040 .350} \times 100 \%=49 \%$

Artinya:

Setiap Rp. 1,00 hutang lancar akan dijamin dengan kas dan bank sebesar Rp. 0,49,--

$\underline{\text { Tahun } 2015}$

Rasio Kas $=\frac{9.530 .000+9.550 .000}{25.790 .640}$ X $100 \%=74 \%$

Artinya:

Setiap Rp. 1,00 hutang lancar akan dijamin dengan kas dan bank sebesar Rp. 0,55,-.

$\underline{\text { Tahun } 2016}$

Rasio Kas $=\frac{7.840 .000+11.290 .500}{47.191 .500} \times 100 \%=41 \%$

Artinya:

Setiap Rp. 1,00 hutang lancar akan dijamin dengan kas dan bank sebesar Rp. 0,41,-.

$\underline{\text { Tahun } 2017}$

Rasio Kas $=\frac{5.400 .000+10.880 .000}{42.418 .000} \times 100 \%=38 \%$

Artinya:

Setiap Rp. 1,00 hutang lancar akan dijamin dengan kas dan bank sebesar Rp. 0,38,--

2. Rasio Solvabilitas

Rasio solvabilitas ini digunakan untuk menggambarkan kemampuan perusahaan dalam membayar kewajiban jangka panjangnya atau kewajiban-kewajiban apabila perusahaan dilikuidasi. Rasio ini dihitung dari pos-pos yang sifatnya jangka panjang. Perhitungan rasio hutang atas aktiva dan rasio hutang atas modal pada PT. Kapuas Tata Steel Banjarbaru untuk tahun 2013, 2014, 2015, 2016 dan 2017 ditunjukkan pada Tabel 9.

Tabel 9. Rasio Solvabilitas PT. Kapuas Tata Steel Banjarbaru Tahun 2013-2017

\begin{tabular}{cccccccc}
\hline No & Jenis Rasio & 2013 & 2014 & 2015 & 2016 & 2017 & Standar Industri \\
\hline 1 & $D A R$ & $64 \%$ & $64 \%$ & $64 \%$ & $90 \%$ & $70 \%$ & $35 \%$ \\
\hline 2 & $D E R$ & $211 \%$ & $205 \%$ & $205 \%$ & $366 \%$ & $366 \%$ & $90 \%$ \\
\hline
\end{tabular}

3. Rasio Aktivitas

Rasio aktivitas (activity ratio) merupakan rasio yang digunakan untuk mengukur efektivitas perusahaan dalam menggunakan aktiva yang dimilikinya. Rasio ini dihitung dari perputaran piutang dan total aset yang dimiliki serta perputaran persediaan. Perhitungan perputaran piutang, perputaran total aktiva, dan perputaran persediaan pada PT. Kapuas Tata Steel Banjarbaru untuk tahun 2013, 2014, 2015, 2016 dan 2017 ditunjukkan pada Tabel 10. 
Tabel 10. Rasio Aktivitas PT. Kapuas Tata Steel Banjarbaru Tahun 2013-2017

\begin{tabular}{cccccccc}
\hline No & Jenis Rasio & $\mathbf{2 0 1 3}$ & $\mathbf{2 0 1 4}$ & $\mathbf{2 0 1 5}$ & $\mathbf{2 0 1 6}$ & $\mathbf{2 0 1 7}$ & $\begin{array}{c}\text { Standar } \\
\text { Industri }\end{array}$ \\
\hline 1 & $R T O$ & $12 \mathrm{kali}$ & $11 \mathrm{kali}$ & $11 \mathrm{kali}$ & $17 \mathrm{kali}$ & $16 \mathrm{kali}$ & $15 \mathrm{kali}$ \\
\hline 2 & $T A T$ & $1 \mathrm{kali}$ & $1 \mathrm{kali}$ & $2 \mathrm{kali}$ & $1 \mathrm{kali}$ & $2 \mathrm{kali}$ & $2 \mathrm{kali}$ \\
\hline 3 & $I T O$ & $11 \mathrm{kali}$ & $9 \mathrm{kali}$ & $11 \mathrm{kali}$ & $12 \mathrm{kali}$ & $12 \mathrm{kali}$ & $20 \mathrm{kali}$ \\
\hline
\end{tabular}

4. Rasio Profitabilitas

Rasio profitabilitas merupakan rasio untuk menilai kemampuan perusahaan dalam mencari keuntungan. Dari perhitungan rasio, dapat dilihat kondisi pengukuran kinerja keuangan melalui rasio profitabilitas pada PT. Kapuas Tata Steel Banjarbaru dari tahun 2013 - 2017 seperti ditunjukkan pada Tabel 11.

Tabel 11. Rasio Profitabilitas PT. Kapuas Tata Steel Banjarbaru Tahun 2013-2017

\begin{tabular}{cccccccc}
\hline No & Jenis Rasio & 2013 & 2014 & 2015 & 2016 & 2017 & Standar Industri \\
\hline 1 & Profit Margin & $0,045 \%$ & $0,043 \%$ & $0,030 \%$ & $0,063 \%$ & $0,068 \%$ & $20 \%$ \\
\hline 2 & ROA & $6 \%$ & $5 \%$ & $5 \%$ & $8 \%$ & $11 \%$ & $30 \%$ \\
\hline 3 & ROE & $16 \%$ & $14 \%$ & $14 \%$ & $28 \%$ & $36 \%$ & $40 \%$ \\
\hline
\end{tabular}

Profit margin pada PT. Kapuas Tata Steel Banjarbaru dari tahun 2013 - 2017 mengalami peningkatan, dimana yang terbesar terjadi pada tahun 2017 sebanyak 0,068\%. Pada tahun 2013-2017 profit margin dikatakan tidak baik dikarenakan masih berada dibawah standar industri sebesar 20\%. Return On Asset (ROA) pada PT. Kapuas Tata Steel Banjarbaru dari tahun 2013 - 2017 mengalami peningkatan. Pada tahun 2013-2017. Tingkat Return On Asset (ROA) dikatakan tidak baik dikarenakan dibawah standar industri sebesar 30\%. Return On Equity (ROE) pada PT. Kapuas Tata Steel Banjarbaru dari tahun 2013 - 2017 mengalami peningkatan. Pada tahun 2013-2017 tingkat Return On Equity (ROE) dikatakan tidak baik dikarenakan dibawah standar industri sebesar $40 \%$.

\section{Kesimpulan}

Analisis kinerja keuangan pada PT. Kapuas Tata Steel Banjarbaru tahun 2013-2017 yaitu tingkat rasio likuiditas mengalami fluktuatif (naik/turun), dimana pada tahun 2015 dikatakan baik karena memenuhi standar industri. Tingkat rasio solvabilitas PT. Kapuas Tata Steel Banjarbaru masih dianggap kurang baik karena pada tahun 2013-2017 berada di atas rata-rata industri. Tingkat rasio aktivitas PT. Kapuas Tata Steel Banjarbaru mengalami fluktuatif, dimana tahun 2016-2017 dikatakan baik karena terjadi melebihi standar industri.

Disarankan sebaiknya perusahaan memperbaiki tingkat likuiditas dan solvabilitasnya yang selama ini terjadi kenaikan pada piutang, hutang lancar dan hutang jangka panjang setiap tahunnya dengan cara melunasi hutang-hutangnya dan meningkatkan lagi penerimaan jasanya. Dari ukuran efesiensi pada rasio likuiditas dan solvabilitas perusahaan diharapkan dapat meningkatkan laju efisiensi operasinya pada rasio likuiditas dan solvabilitas agar hutang-hutang dari perusahaan tersebut dapat terselesaikan dengan jelas dan tepat sesuai dengan pendapatan yang diperoleh perusahaan. Sedangkan pada rasio aktivitas dan profitabilitas, perusahaan hendaknya dapat meningkatkan efektivitas dalam menggunakan aktiva yang dimiliki dan menggali lebih potensi (inovasi) yang dapat dijadikan pendapatan oleh perusahaan. 


\section{DAFTAR PUSTAKA}

Galih Retno Aryati, 2014, Penerapan Laporan Keuangan Sebagai Alat Untuk Menilai Kinerja Keuangan Pada PT. Sinar Jaya Lestari Yogyakarta, http://www.universitas.negeri.yogyakarta.go.id (20/10/17)

Kasmir. 2015. Analisis Laporan Keuangan. Rajawali Pers.Jakarta.

Keown, Arthur J dkk. 2014. Manajemen Keuangan: Prinsip-prinsip dan Aplikasi .Indeks. Jakarta.

Harahap, Sofyan Sjafrie, 2014, Analisis Kinerja Keuangan, Raja Grafindo, Jakarta

Raharjo, Budi. 2013. Laporan Keuangan Perusahaan. Universitas Gadjah Mada Press. Yogyakarta.

Sawir, Agnes. 2013. Analisis Kinerja Keuangan dan Perencanaan Keuangan Perusahaan.Gramedia Pustaka Utama. Jakarta.

Soemarso. 2014. Akuntansi Suatu Pengantar. Edisi kelima buku 1.Salemba Empat. Jakarta.

Sugiono, Arief dan Untung, Edy. 2013. Panduan Praktis Dasar Analisis Laporan Keuangan. Grasindo. Jakarta.

Sri Widariati, 2016, Analisis Laporan Keuangan Untuk Mengukur Kinerja Keuangan Pada CV. Wijaya Ekspres Banjarmasin, Skripsi, Perpustakaan STIE Pancasetia, Banjarmasin

Van Horne, James C dkk. 2014. Prinsip - Prinsip Manajemen Keuangan. Edisi keduabelas buku 1. Salemba Empat. Jakarta.

Wild, John J dkk. 2015. Analisis Laporan Keuangan. Edisi kedelapan buku 1. Salemba Empat. Jakarta.

Zagladi, Arief Noviarakhman, Fredy Jayen, Sutrisno dan Melania, 2017, Pedoman Penulisan Skripsi, STIE Pancasetia, Banjarmasin

Zagladi, Arief Noviarakhman, 2014, Penerapan Rasio Keuangan Sebagai Salah Satu Alat Pengambilan Keputusan Dalam Mengukur Kinerja Keuangan Pada PT. Srigunting, http://sia.stiepancasetia.banjarmasin (20/10/17) 